\title{
Phosphorylation of G Protein-Coupled Receptors: From the Barcode Hypothesis to the Flute Model
}

\author{
Zhao Yang, Fan Yang, Daolai Zhang, Zhixin Liu, Amy Lin, Chuan Liu, Peng Xiao, Xiao Yu, \\ and Jin-Peng Sun
}

Key Laboratory Experimental Teratology of the Ministry of Education and Department of Biochemistry and Molecular Biology (Z.Y., Z.L., C.L., P.X., J.-P.S.), Department of Physiology (F.Y., X.Y.), Shandong University School of Medicine, Jinan, Shandong, People's Republic of China; School of Pharmacy, Binzhou Medical University, Yantai, Shandong, People's Republic of China (D.Z.); School of Medicine, Duke University, Durham, North Carolina (A.L., J.-P.S.)

Received December 10, 2016; accepted February 23, 2017

\section{ABSTRACT}

Seven transmembrane G protein-coupled receptors (GPCRs) are often phosphorylated at the $\mathrm{C}$ terminus and on intracellular loops in response to various extracellular stimuli. Phosphorylation of GPCRs by GPCR kinases and certain other kinases can promote the recruitment of arrestin molecules. The arrestins critically regulate GPCR functions not only by mediating receptor desensitization and internalization, but also by redirecting signaling to $G$ protein-independent pathways via interactions with numerous downstream effector molecules. Accumulating evidence over the past decade has given rise to the phospho-barcode hypothesis, which states that ligandspecific phosphorylation patterns of a receptor direct its distinct functional outcomes. Our recent work using unnatural amino acid incorporation and fluorine-19 nuclear magnetic resonance ( $\left.{ }^{19} \mathrm{~F}-\mathrm{NMR}\right)$ spectroscopy led to the flute model, which provides preliminary insight into the receptor phosphocoding mechanism, by which receptor phosphorylation patterns are recognized by an array of phosphate-binding pockets on arrestin and are translated into distinct conformations. These selective conformations are recognized by various effector molecules downstream of arrestin. The phosphobarcoding mechanism enables arrestin to recognize a wide range of phosphorylation patterns of GPCRs, contributing to their diverse functions.

\section{Introduction}

Seven transmembrane-spanning G protein-coupled receptors (GPCRs) comprise the largest known membrane protein family encoded by the human genome, and GPCRs regulate almost all the known physiologic processes in humans by converting a broad range of extracellular stimuli (ranging from light to hormones and neurotransmitters) to intracellular signals (Ritter and Hall, 2009; Manglik and Kobilka, 2014; Wisler et al., 2014; Dohlman, 2015). Upon ligand binding and

This work was supported by the National Key Basic Research Program of China [Grant 2013CB967700]; the Fundamental Research Funds of Shandong University [Grants 2014JC029, 2016HW005]; the National Natural Science Foundation of China [Grants 31470789, 31611540337]; the Shandong Natural Science Fund for Distinguished Young Scholars [Grants JQ201320, JQ201517]; and the Program for Changjiang Scholars and Innovative Research Team in University [Grant IRT13028].

Z.Y. and F.Y. contributed equally to this work.

https://doi.org/10.1124/mol.116.107839. activation, most GPCRs "floating" on the plasma membrane are phosphorylated at sites located on intracellular loops or C-terminal tails (Table 1).

Many different phosphorylation sites in different GPCRs have been identified, mostly by mass spectrometry or phospho-specific antibodies. By contrast, the functions of receptor phosphorylation are often established by mutagenesis both in vitro and in vivo (Budd et al., 2000; Jones et al., 2007; Busillo et al., 2010; Bradley et al., 2016). In cells, the phosphorylation process is mediated by at least two classes of serine/threonine kinases, including the second messenger-dependent (e.g., PKA and protein kinase C $[\mathrm{PKC}]$ ) and -independent kinases (i.e., GPCR kinases [GRKs]) (Lefkowitz, 1998). As a classic paradigm, phosphorylation of receptors by the former type of kinases is independent of ligand binding and directly uncouples the receptors from their cognate $\mathrm{G}$ proteins, leading to heterologous desensitization (Hausdorff et al., 1990). In contrast, receptor phosphorylation

ABBREVIATIONS: Akt, protein kinase $\mathrm{B} ; \beta_{2} \mathrm{AR}, \beta_{2}$-adrenergic receptor; AT1aR, angiotensin II receptor type I; BRET, bioluminescence resonance energy transfer; ERK, extracellular signal-regulated kinase; ${ }^{19} \mathrm{~F}-\mathrm{NMR}$, fluorine-19 nuclear magnetic resonance; GPCR, G protein-coupled receptor; GPR120, G-protein coupled receptor 120; GRK, G protein-coupled receptor kinase; GRK2, G protein-coupled receptor kinase 2, or $\beta$-adrenergic receptor kinase 1; GRK2pp, GRK2-phosphopeptides; ICL3, third intracellular loop; M3-mAChR, M3-muscarinic acetylcholine receptor; PKA, protein kinase A; PKC, protein kinase C; Thr, threonine; V2R, V2 vasopressin receptor. 


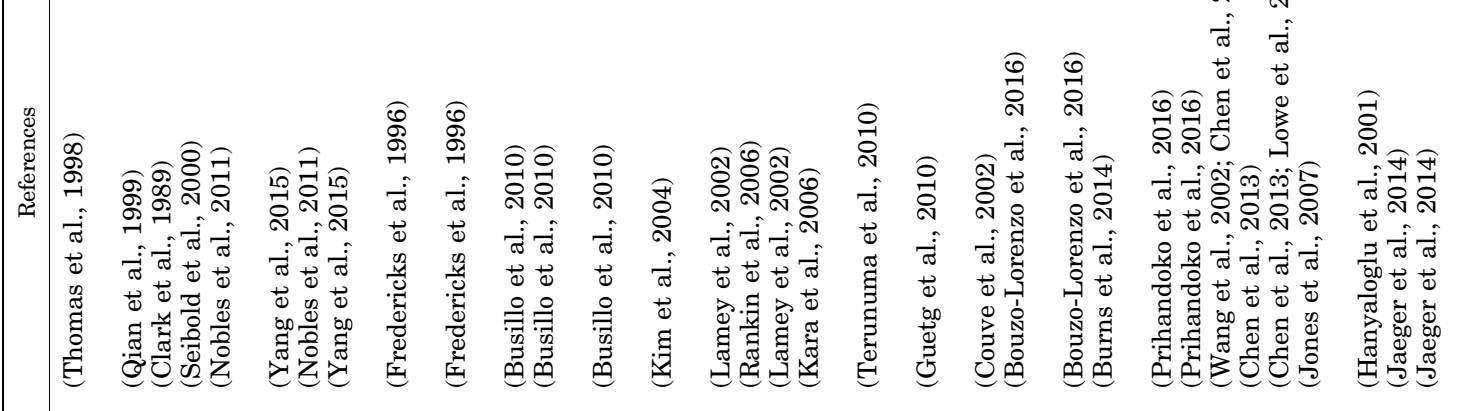
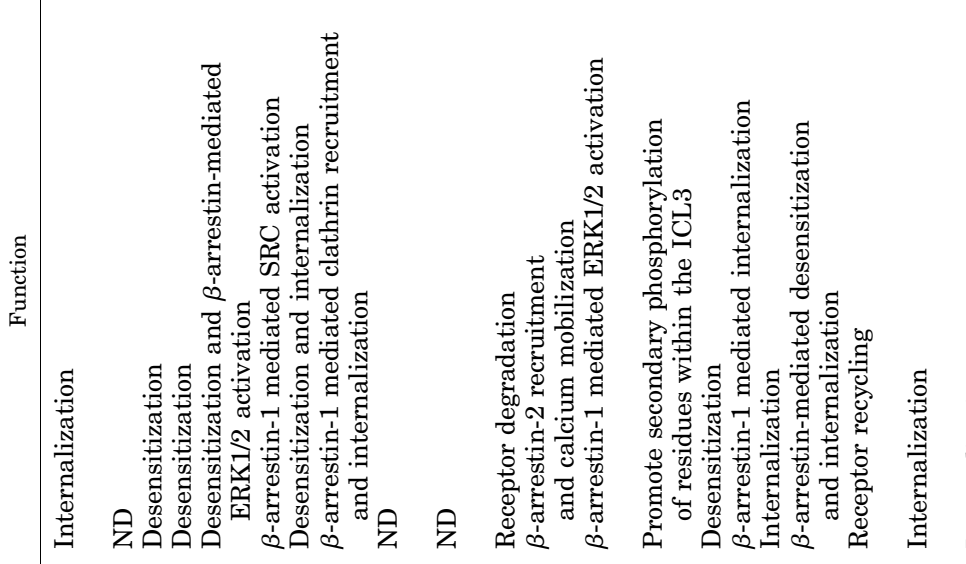

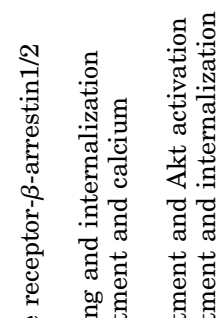

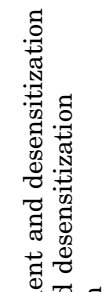

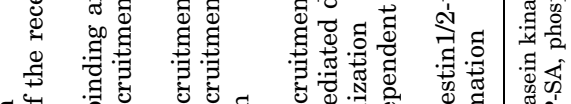

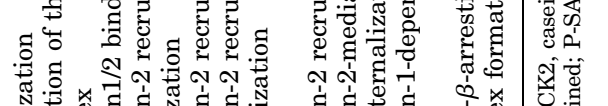

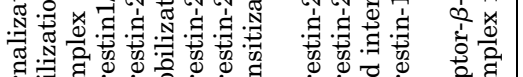

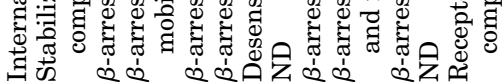

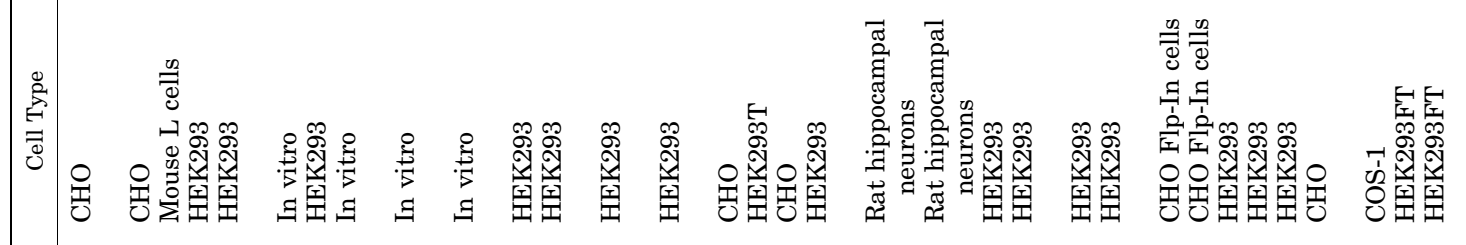

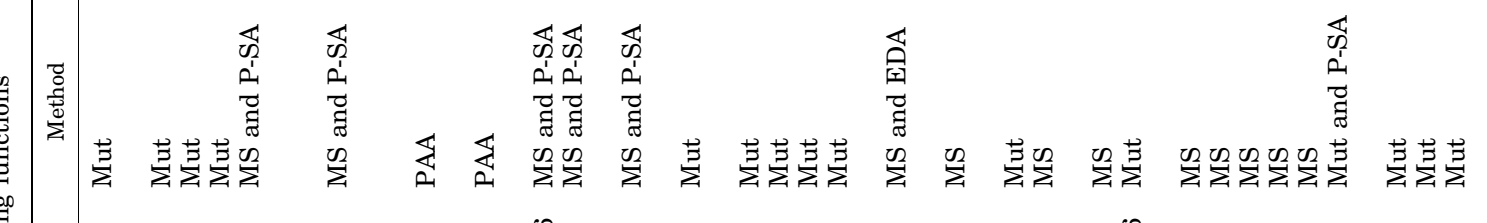

药

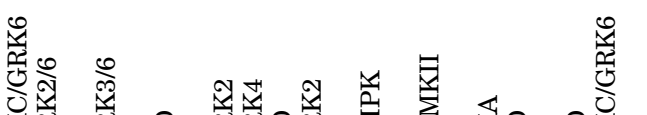

$\exists \quad$ 密

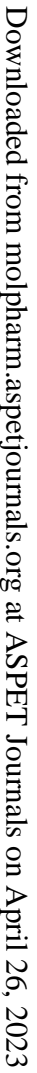

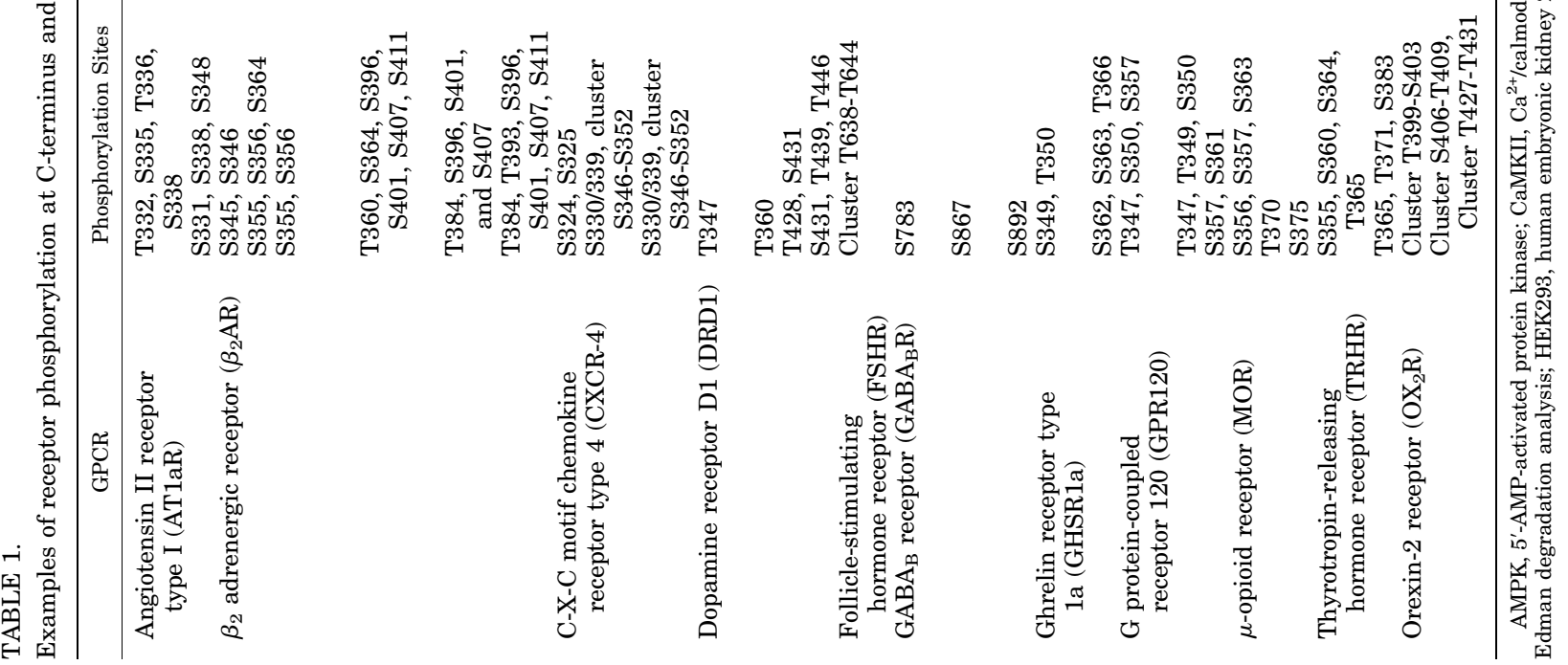


by GRKs, a kinase family consisting of seven members, is ligand-stimulation dependent and is followed by the recruitment of arrestin molecules to the receptor that sterically inhibits G protein coupling, initiating homologous desensitization (Pitcher et al., 1992; Tobin et al., 2008; Gurevich et al., 2012).

The functional importance of receptor phosphorylation has been demonstrated in many aspects of GPCR regulation other than desensitization. Studies of the PKA-regulated $\beta_{2^{-}}$ adrenergic receptor $\left(\beta_{2} \mathrm{AR}\right)$ phosphorylation have shown that it not only decreases the coupling of $\beta_{2} A R$ to the $G_{s}$ protein but also switches this coupling to the $G_{i}$ protein (Daaka et al., 1997; Lefkowitz et al., 2002). Receptor phosphorylation by GRKs promotes the coupling of arrestins to the activated receptors, which then mediate $G$ protein-independent signaling.

Four isoforms of arrestin have been identified: arrestin-1 and arrestin-4 are restricted to the visual system and accordingly are named "visual arrestins" (Wilden et al., 1986; Craft et al., 1994). The other two isoforms, $\beta$-arrestin1 and $\beta$-arrestin-2, are ubiquitously distributed (Lohse et al., 1990; Attramadal et al., 1992). Arrestin binding facilitates the internalization of nonvisual receptors via clathrin-dependent endocytic machinery (McDonald and Lefkowitz, 2001; Shenoy and Lefkowitz, 2003).

Moreover, arrestin-mediated receptor trafficking initiates a second wave of receptor signaling via interactions with a growing list of signaling molecules such as SRC protooncogene, non-receptor tyrosine kinase (SRC), Raf-1 protooncogene, serine/threonine kinase (Raf-1), protein kinase B (Akt), extracellular signal-regulated kinase 1 and 2 (ERK1/2), phosphodiesterase (PDE), and diacylglycerol kinases (Luttrell et al., 1999; Barki-Harrington and Rockman, 2008; Xiao et al., 2010; Reiter et al., 2012; Wang et al., 2014; Ning et al., 2015; Dong et al., 2016; Kumari et al., 2016). In particular, activation of a single receptor, such as angiotensin II receptor type I (AT1aR), recruits more than 220 signaling proteins to the receptor/arrestin complexes (Xiao et al., 2010). Given the potential multiple phosphorylation sites located on GPCRs, the possibility of a mechanism that mediates the phosphorylation pattern of the receptor such that specific signaling molecules are recruited through arrestin is intriguing.

In 2011, two seminal studies brought the barcode hypothesis of GPCR phosphorylation to light by studying two prototypic GPCRs, $\beta_{2} \mathrm{AR}$ and M3-muscarinic acetylcholine receptor (M3-mAChR) (Butcher et al., 2011; Nobles et al., 2011). Whereas distinct phosphorylation patterns of the $\beta_{2} \mathrm{AR}$ induced by different GRKs are correlated with different cellular functions (Nobles et al., 2011), M3-mAChR is differentially phosphorylated in various cells and tissues, supporting a role for receptor phosphorylation in directing physiologically relevant receptor signaling (Butcher et al., 2011). Therefore, the phosphorylation of distinct sites on the GPCRs may constitute a barcode that dictates the downstream signaling outcomes of the receptor.

Because different ligands that bind to a single receptor might induce distinct patterns of receptor phosphorylation, the pleiotropic functionalities and therapeutic importance of ligand-specific, phosphorylation/arrestin-dependent signaling have been emerging (Jean-Charles et al., 2016; Peterhans et al., 2016; Smith and Rajagopal, 2016; Xiao and Liu, 2016; Latorraca et al., 2017). However, there is little primary phosphorylation pattern identity among different receptors, so the mechanism by which the phospho-barcode is recognized and then converted to specific signaling remains largely unknown, although many of the GPCRs share similar signaling pathways, such as arrestin-mediated ERK or SRC signaling.

Recently, using a newly developed unnatural amino acid incorporation technique combined with fluorine-19 nuclear magnetic resonance $\left({ }^{19} \mathrm{~F}\right.$-NMR) spectroscopy (NeumannStaubitz and Neumann, 2016), we showed that the phosphorylation barcode of the receptor is specifically recognized by the $\mathrm{N}$-terminal half of arrestin (Yang et al., 2015). The 10 phosphate-binding sites located at the $\mathrm{N}$ domain of arrestin act as sensors on the phosphorylated receptor C-terminal tail, which in theory enables more than 1000 specific arrestin conformations for downstream signaling outcomes. Given this recent progress, we will review the current knowledge of GPCR phosphorylation, summarize the recent studies that support the barcode hypothesis, and highlight the emerging structural mechanism of GPCR phospho-coding.

\section{Phosphorylation of the GPCR at Multiple Sites}

Stimulus-induced GPCR phosphorylation was first reported for rhodopsin in 1972, which led to the subsequent identification and isolation of rhodopsin kinase (GRK1) (Kühn and Dreyer, 1972; Weller et al., 1975). A similar observation was made in the $\beta_{2} \mathrm{AR}$ system, where the deactivation of agonistoccupied $\beta_{2} \mathrm{AR}$ was found to be tightly associated with receptor phosphorylation by a $\beta$-adrenergic receptor kinase $(\beta A R K 1$ or GRK2) (Benovic et al., 1986; Stadel et al., 1983). These findings identified the pivotal role of phosphorylation in the desensitization mechanism of GPCRs. Since then, seven isoforms of GRKs, referred to as GRK 1-7, have been identified (Pitcher et al., 1998). GRK 2, 3, 5, and 6 are ubiquitously expressed and serve as important determinants of phosphorylation patterns in most nonvisual system GPCRs (Krupnick and Benovic, 1998; Butcher et al., 2012).

In addition to GRKs, GPCR can also be phosphorylated by second messenger-regulated kinases and some other kinases (Benovic et al., 1985; Pitcher et al., 1992; Kelly et al., 2008; Tobin, 2008). For example, casein kinase-induced phosphorylation plays an important role for $\mathrm{M} 3-\mathrm{mAChR}$ and thyrotropin-releasing hormone receptor, whereas $\mathrm{Ca}^{2+} /$ calmodulin-dependent protein kinase II (CaMKII)-induced phosphorylation has been identified in the dopamine receptor $\mathrm{D} 3, \mathrm{GABA}_{\mathrm{B}}$ receptor, and $\mu$-opioid receptor (Table 1 and Table 2) (Budd et al., 2001; Hanyaloglu et al., 2001; Torrecilla et al., 2007; Liu et al., 2009; Guetg et al., 2010; Chen et al., 2013). These kinases are important "composers" of receptor phosphorylation patterns and, therefore, specifically regulate receptor functions.

The very first mutagenesis analyses of rhodopsin and $\beta_{2} \mathrm{AR}$ determined that these receptors are phosphorylated at multiple sites (Wilden and Kühn, 1982; Bouvier et al., 1988). As discussed previously, the involvement of a variety of protein kinases suggests that undergoing multiple phosphorylation events might be a common phenomenon among the GPCR superfamily, and this has been confirmed by numerous studies mapping phosphorylation sites on GPCRs using different techniques and approaches.

Whereas site-directed mutagenesis was considered the primary method for identifying the potential phosphorylation residues in early studies, multiple novel techniques have been 


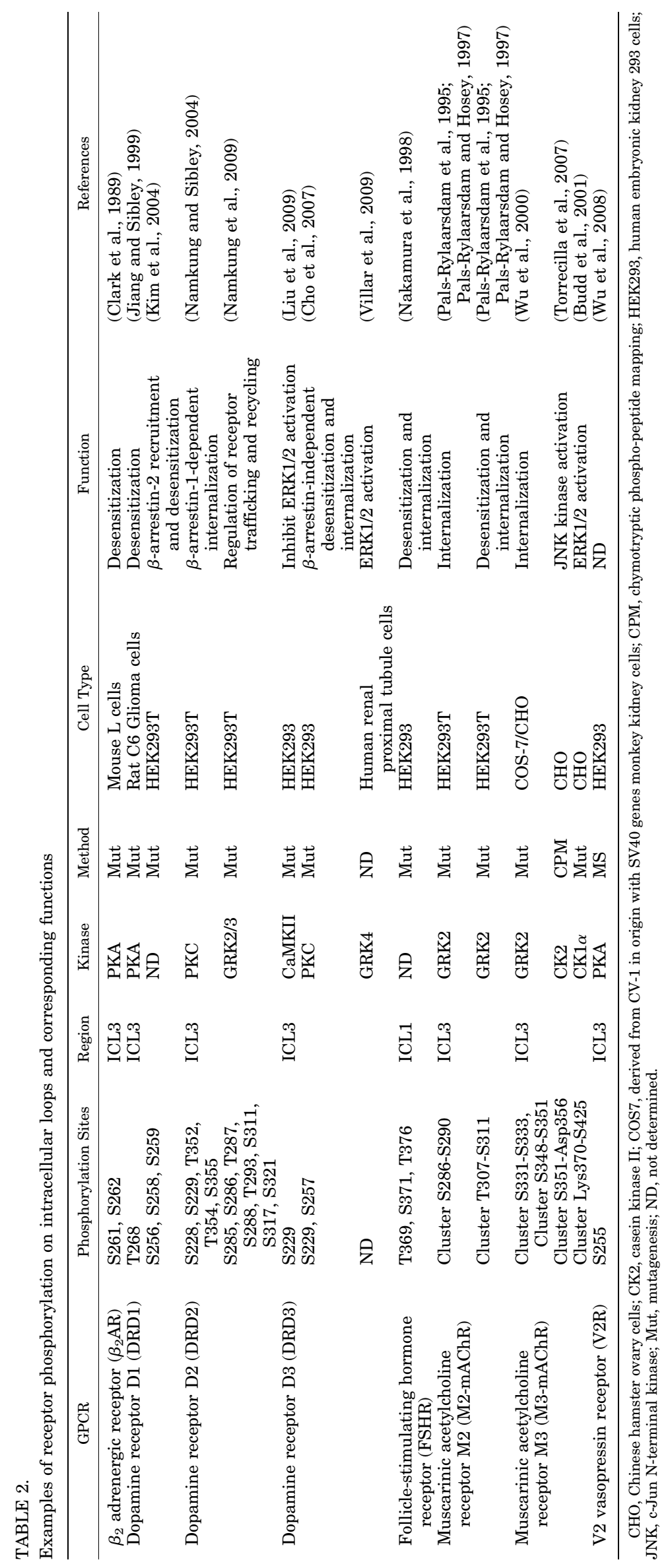


developed and applied for more precise mapping of phosphorylation sites in an increasing number of GPCRs (Table 1). For example, using mass spectrometry analysis and phosphospecific antibodies, three serines and two threonines at the $\mathrm{C}$-tail of the ghrelin receptor and 14 serines and two threonines at the C-tail and on the third intracellular loop (ICL3) of the M3-mAChR were identified as phosphorylation sites (Butcher et al., 2011; Bouzo-Lorenzo et al., 2016). Furthermore, whereas the phosphorylation sites of GPCRs are primarily located at the C-tail and on the ICL3, there is increasing evidence that phosphorylation events could also occur on other cytoplasmic regions, including the first and second intracellular loops (Table 2) (Nakamura et al., 1998; Celver et al., 2001; Nobles et al., 2011).

One interesting feature of GPCR phosphorylation is its dynamics and sequential fashion. For example, the phosphorylation of the primary sites in rhodopsin permits the phosphorylation of the other residues, and this has also been observed in several other GPCRs (Ohguro et al., 1993). Studies of the phosphorylation profile of the D1 dopamine receptor indicated that although the mutation of a cluster of serines within the ICL3 resulted in severely impaired ligand-induced receptor phosphorylation and desensitization, C-terminal truncation at a selective threonine (Thr347) led to reduced receptor phosphorylation but normal arrestin-mediated desensitization (Kim et al., 2004). This result suggested that primary phosphorylation of the specific sites on the C-tail of the $\mathrm{D} 1$ dopamine receptor is required for secondary phosphorylation of the residues within ICL3, which leads to receptor desensitization. This type of hierarchical phosphorylation has also been described for the A3 adenosine receptor (Palmer and Stiles, 2000) and the $\delta$-opioid receptor (Kouhen et al., 2000), suggesting that it is a general phenomenon.

Taken together, these findings indicate that agonists promote GPCR phosphorylation at multiple sites, including the C-tail, the ICL3, and the first and second intracellular loops. The phosphorylation of the receptor is highly heterologous and dynamic, and this can generate different phosphorylation patterns at distinct cellular locations and specific time points after agonist stimulation, thereby providing a physical basis for a phosphorylation barcode hypothesis.

\section{Diverse Signaling Regulated by Phosphorylation of GPCRs: A Phospho-Barcode Hypothesis}

By binding to phosphorylated receptors, arrestins regulate the desensitization and internalization of most GPCRs and redirect signaling to numerous $G$ protein-independent pathways. Many receptors share similar signaling pathways, such as arrestin-mediated ERK1/2 or SRC signaling (Luttrell et al., 1999; Ahn et al., 2004; Wang et al., 2014; Ning et al., 2015; Yang et al., 2015). Given this similarity, it is possible that the coupling of arrestins to activated and phosphorylated receptors is nonspecific and leads to the same signaling downstream of different receptors. However, studies have shown that different GRKs regulate distinct functions of GPCRs. For instance, research on the AT1aR and V2 vasopressin receptor (V2R) showed that GRK2 and GRK3 are indispensable for agonist-dependent $\beta$-arrestin recruitment and receptor desensitization, whereas GRK5 and GRK6 are primarily responsible for $\beta$-arrestin-2-mediated ERK1/2 signaling (Kim et al., 2005; Ren et al., 2005). These findings have raised the question of whether these distinct functional outcomes are generated by signaling arising from different receptor phosphorylation events or by the activity of these GRKs toward other substrates. Therefore, an elegant study was subsequently performed to investigate the phospho-coding of the $\beta_{2} \mathrm{AR}$ using mass spectrometry and cellular approaches (Nobles et al., 2011).

In $\beta_{2}$ AR-expressing human embryonic kidney 293 (HEK293) cells, GRK6-dependent phosphorylation promotes $\beta$-arrestin2 -mediated ERK1/2 signaling, whereas GRK2-dependent phosphorylation functions in the opposite manner yet plays a more important role in receptor internalization. Consistent with these findings, a full agonist of $\beta_{2} \mathrm{AR}$ stimulates robust phosphorylation at both GRK2 and GRK6 sites, whereas a $\beta$-arrestin-biased ligand is able to initiate $\beta_{2} \mathrm{AR}$ phosphorylation only at GRK6 sites. Moreover, bioluminescence resonance energy transfer (BRET) analysis has shown that distinct phosphorylation patterns of $\beta_{2} \mathrm{AR}$ induced by GRK2 or GRK6 are correlated with different $\beta$-arrestin- 2 conformations (Nobles et al., 2011).

Similarly, different GRK subtypes also encode specific functional capabilities and conformational changes of $\beta$-arrestin-1, as shown by our recent studies. Our data indicated that by interacting with $\beta$-arresin-1, the GRK2induced $\beta_{2} \mathrm{AR}$ phosphorylation pattern selectively recruits clathrin, whereas the GRK-6-regulated phosphorylation pattern selectively activates SRC (Yang et al., 2015). Collectively, these studies provide evidence that different GRKs phosphorylate distinct sites on the receptors and thereby establish a phosphorylation barcode, which in turn affects the conformation of the recruited $\beta$-arrestins by changing the topology of the intracellular face of the receptor, which further dictates $\beta$-arrestin-related cellular functional outcomes (Fig. 1).

The barcode hypothesis has been supported by numerous data from studies of different types of GPCRs, including C-C motif chemokine receptor 7 (Zidar et al., 2009), the free fatty acid receptor G-protein coupled receptor 120 (GPR120) (Prihandoko et al., 2016), and the ghrelin receptor (BouzoLorenzo et al., 2016). For example, the phosphorylation of five residues that are clustered in two separable regions of the C-tail of GPR120 is pivotal for $\beta$-arrestin-2 recruitment (Butcher et al., 2014). The phosphorylation of residues within cluster 1 (Thr347, Thr349, and Ser350) is indispensable for Akt activation, but the phosphorylation of residues within cluster 2 (Ser357 and Ser361) is specifically responsible for arrestin-mediated receptor internalization (Prihandoko et al., 2016). Moreover, studies of subtypes of another multifunctional therapeutic target, the orexin receptor, have demonstrated that phosphorylation of an additional serine/threonine cluster in the C-tail of the orexin-2 receptor establishes a phospho-barcode that is different from that of the orexin-1 receptor, enabling the orexin-2 receptor to form more stable complexes with $\beta$-arrestin and ubiquitin (Dalrymple et al., 2011; Jaeger et al., 2014).

With all the increasing evidence, most of it derived from in vitro studies, supporting the barcode hypothesis, one outstanding question has been how the phosphorylation barcode contributes to the physiologic responses of GPCRs. Recently, progress has been made toward answering this question via a series of studies on M3-mAChR. By combining phosphopeptide mapping, mass spectrometry, and phospho-specific 


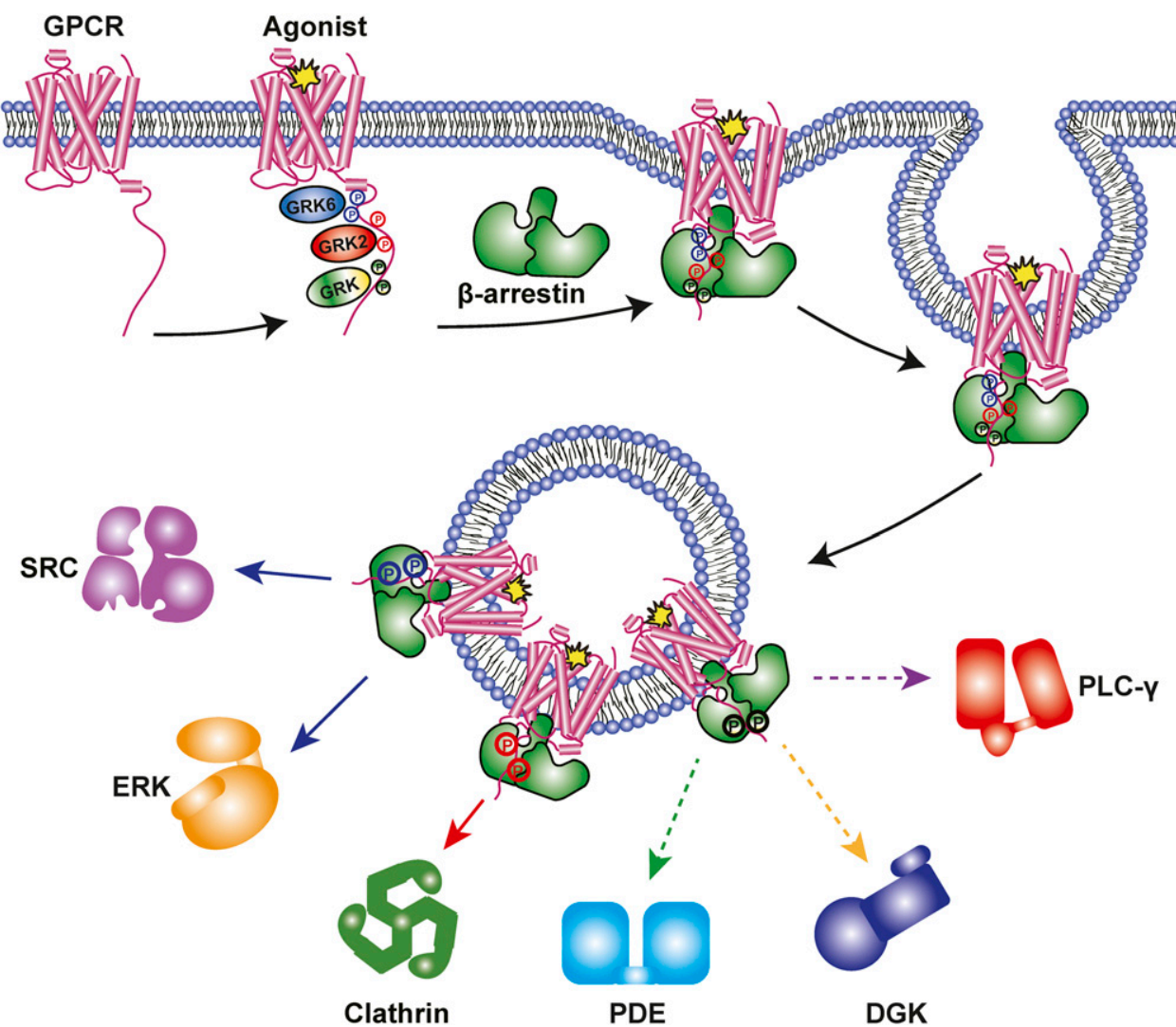

Fig. 1. A model of receptor phosphobarcoding. Most GPCRs are phosphorylated by different kinases at multiple sites upon ligand stimulation, resulting in the recruitment of arrestins, which mediate receptor desensitization and internalization. Different GPCR phosphorylation patterns encoded by different GRKs transduce specific information to arrestins to dictate distinct functional outcomes. Whereas the GRK2-mediated phosphorylation pattern specifically recruits clathrin, the GRK6-mediated phosphorylation pattern selectively activates SRC or ERK1/2. The interactions between arrestin and other effectors, such as phosphodiesterase (PDE) and diacylglycerol kinase (DGK), are potentially regulated by different phospho-barcodes. antibodies, Tobin and colleagues showed that M3-mAChR is differentially phosphorylated in three cell lines, including Chinese hamster ovary (CHO) cells transfected with M3mAChR, mouse insulinoma (MIN6) cells, and cerebellar granule neurons that endogenously express M3-mAChR (Torrecilla et al., 2007; Butcher et al., 2011). Accordingly, different phosphorylation patterns of three serine residues, two of which (Ser384 and Ser412) are within ICL3 and another (Ser577) is at the C-terminus of M3-mAChR, were revealed in the central nervous system, pancreas, and salivary glands of the mouse. Moreover, the phosphorylation profiles at these residues of M3-mAChR, especially at Ser577, were different in response to full or partial agonists administration (Butcher et al., 2011). The kinases that contribute to different phosphorylation patterns and the potential role of arrestins in these processes remain elusive; however, these findings provide compelling evidence that the phosphorylation status of M3-mAChR is ligand dependent and both cell type and tissue specific, thus suggesting a substantial correlation between the phospho-barcode and the functional outcomes of receptor in different physiologic contexts.

To understand the physiologic relevance of receptor phosphorylation, a series of studies was performed using transgenic knock-in mice. Removal of the phosphorylatable sites on M3-mAChR by mutation resulted in the abolition of arrestin recruitment and arrestin-mediated receptor internalization but had little effect on $\mathrm{G}_{\mathrm{q}}$-dependent signaling pathways in terms of $\mathrm{PKC}$ activation and calcium mobilization. Intriguingly, compared with the normal mice, the transgenic mice carrying the phospho-deficient M3-mAChR mutant displayed significant deficiencies in pancreatic insulin secretion (Kong et al., 2010), hippocampal learning and memory (Poulin et al., 2010), and bronchoconstriction regulation (Bradley et al., 2016). In contrast, the transgenic mice behaved normally in terms of M3-mAChR-mediated salivary secretion and weight gain (Bradley et al., 2016), indicating that these physiologic responses are independent of M3-mAChR phosphorylation.

Collectively, these data provide primary insight into the physiologic roles of receptor phosphorylation. However, more animal models that harbor mutants for specific phosphorylation sites of target receptors are required to better understand the significance of barcode hypothesis in vivo and to further link distinct phosphorylation patterns of GPCRs to different physiologic functions. Taken together, these novel findings indicate that the different phosphorylation patterns of GPCRs that might be generated by different kinases, potentially resembling a barcode in the intracellular regions of the receptor, could transduce specific information and dictate distinct functional outcomes (Fig. 1).

However, despite these developments and breakthroughs, it should be noted that the phosphorylation barcode hypothesis is not supported by all studies. For example, a cytoplasmic tail truncation mutant of AT1aR that cannot be phosphorylated by either GRK or PKC was shown to recruit $\beta$-arrestin, albeit in a weaker manner than the wild-type receptor. Strikingly, phosphorylation-deficient AT1aR elicits normal ERK signaling upon agonist stimulation (DeWire et al., 2007). Similarly, for some other GPCRs, such as luteinizing hormone receptor and the D6 chemokine receptor, phosphorylation is not necessarily required for arrestin recruitment (Min and Ascoli, 2000; Galliera et al., 2004). Intriguingly, studies have also suggested that negatively charged amino acids located 
in the ICL3 or C-tail might function as phosphate mimics in these nonphosphorylated receptors and thereby interact with arrestins, contributing to GPCR regulation (Mukherjee et al., 2002; Galliera et al., 2004; Gurevich and Gurevich, 2006; Tobin, 2008).

Nevertheless, considering the relatively low sequence homology, particularly in the intracellular loops and C-terminal domains, among different receptors, it is still difficult to understand how the phospho-barcode selectively directs different arrestin functions. To provide further mechanistic insight, a detailed structural analysis of the interaction between phosphorylated receptors and arrestins is urgently needed.

\section{Structural Basis of GPCR Phospho-Barcoding: A Flute Model}

Mammalian genomes encode $16 \mathrm{G} \alpha, 5 \mathrm{G} \beta$, and $12 \mathrm{G} \gamma$ subunits (Downes and Gautam, 1999; Khan et al., 2013). In contrast, there are only two $\beta$-arrestin isoforms that are ubiquitously distributed. It is therefore unclear how arrestins decipher the phosphorylation barcode and regulate numerous GPCR functions by selectively interacting with a large repertoire of downstream signaling molecules. Early in vitro studies using limited tryptic proteolysis and mass spectrometry analysis revealed that upon binding to a phospho-peptide derived from the $\mathrm{C}$-tail of $\mathrm{V}_{2} \mathrm{R}$, both subtypes of the $\beta$-arrestins undergo significant conformational changes (Xiao et al., 2004; Nobles et al., 2007). The $\mathrm{C}$ terminus of $\beta$-arrestin, which harbors the clathrin-binding site and is primarily responsible for receptor endocytosis, was observed to be exposed upon activation. Moreover, a subtle difference in conformational changes was observed between the two subtypes of $\beta$-arrestins, predominantly locating in the connecting region between the $\mathrm{N}$ and $\mathrm{C}$ domains.

It was then hypothesized that arrestins are able to adopt multiple conformations, which connect to different signaling pathways (Gurevich and Gurevich, 2006). Subsequently, structural changes in $\beta$-arrestin- 2 were detected using an intramolecular BRET-based biosensor upon stimulation of $\mathrm{AT} 1 \mathrm{aR}, \beta_{2} \mathrm{AR}$, or parathyroid hormone 1 receptor (PTH1R) by agonists (Shukla et al., 2008). Further evidence supporting this notion came from a recent study using an improved BRET sensor with a panel of intramolecular fluorescein arsenical hairpins (FlAsH) inserted in specific loops of $\beta$-arrestin-2, revealing that different $\beta$-arrestin- 2 conformational changes generated distinct "conformational signatures" correlated with different downstream functions (Lee et al., 2016).

The crystal structures of $\mathrm{V}_{2} \mathrm{R}$ phospho-peptide-bound $\beta$-arrestin-1 and a fusion complex of constitutively active rhodopsin bound to a preactivated visual arrestin were recently determined (Shukla et al., 2013; Kang et al., 2015). In comparison with the inactive conformation, the activated arrestin molecule undergoes displacement of its $\mathrm{C}$ terminus from the $\mathrm{N}$ domain and approximately $20^{\circ}$ twisting between its $\mathrm{N}$ and $\mathrm{C}$ domains that repositions several important loops, including the finger, middle, and lariat loops, and thereby allows interactions with the seven-transmembrane core of the GPCR. Importantly, the interaction between $\beta$-arrestin- 1 and $\beta_{2} \mathrm{~V}_{2} \mathrm{R}$ (modified $\beta_{2} \mathrm{AR}$ with its $\mathrm{C}$ terminus replaced by that of $V_{2} R$ ) was recently visualized by negative stain electron microscopy, which has substantially improved our understanding of GPCR-arrestin interaction (Shukla et al., 2014).

Collectively, these studies suggest that $\beta$-arrestin first interacts with the phosphorylated C-tail of the activated receptor via its $\mathrm{N}$ domain and subsequently forms tighter engagement with the transmembrane core of the receptor. These marked conformational changes of arrestin and the biphasic mechanism of GPCR- $\beta$-arrestin interaction shed the first light on structural information during arrestin activation. However, the crystal structure represents a static profile of only a single activated arrestin molecule, limiting any in-depth analysis of the structural changes of arrestin that correlate with differential signaling. Therefore, the detailed mechanism by which arrestins precisely transmit the phospho-coding information to downstream effectors remains to be elucidated.

To better characterize the conformational changes in arrestin and to uncover the phospho-barcoding mechanism for selective signaling, we incorporated ${ }^{19} \mathrm{~F}-\mathrm{NMR}$ probes at seven potential phosphate-binding pockets to sense negatively charged interactions and at seven other sites to monitor the conformational changes in $\beta$-arrestin- 1 by using unnatural amino acid 3,5-difluorotyrosine (F2Y) incorporation (Yang et al., 2015). We showed that $\beta$-arrestin- 1 interacts with different types of phospho-peptides, which were synthesized to mimic different phospho-barcodes corresponding to the $\mathrm{C}$ terminus of $\beta_{2} \mathrm{AR}$ phosphorylated by GRK2, GRK6, or PKA, through different phospho-interaction patterns correlated with selective functional outcomes. Intriguingly, whereas GRK2-phosphopeptides (GRK2pp) bind to $\beta$-arrestin- 1 in a 1-4-6-7 pattern and mediate the clathrin interaction,

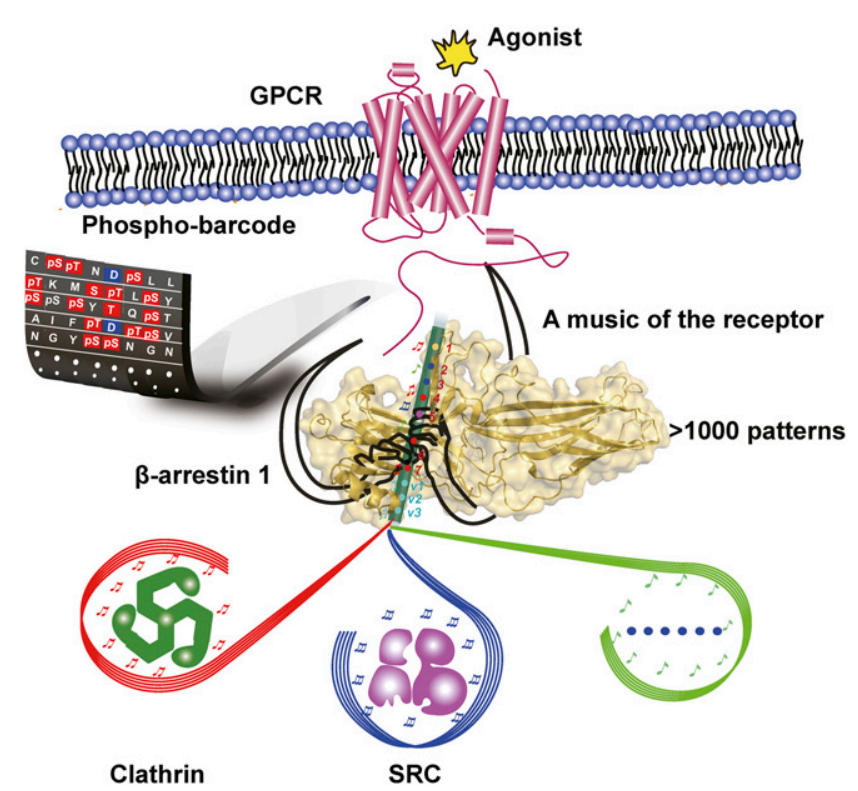

Fig. 2. The flute model for the phospho-barcoding mechanism of arrestin signaling. The 10 phosphate-binding sites located in the N-terminal region of arrestin function as sensors of the phospho-message in the receptor C-tail or the intracellular loops. A phospho-barcode of 1-4-6-7 directs clathrin recruitment and the endocytic function of arrestin, whereas a phospho-barcode of 1-5 directs SRC recruitment and signaling. There are theoretically more than 1000 phospho-patterns that produce many arrestin conformations, dictating numerous downstream effector interactions. 
GRK6-phosphopeptides (GRK6pp) interact with $\beta$-arrestin-1 in a 1-5 pattern and specifically elicit SRC signaling.

Moreover, analyses of ${ }^{19} \mathrm{~F}$-NMR spectra at specific $\beta$-arrestin1 sites other than phospho-interaction regions enabled us to show that phosphate binding to specific sites generates different conformations of arrestin at remote locations. For example, the binding of GRK2pp induces a specific conformational change of $\beta$-arrestin-1 at Y249 and L338 located in different loops. These structural states were specifically recognized by the subsequent binding of clathrin. Conversely, the binding of GRK6pp to $\beta$-arrestin-1 elicits a unique structural alteration at F277 located in the lariat loop. Deletion of the partial lariat loop encompassing F277 abolishes the GRK6pp-induced recruitment of SRC.

These findings collectively support a potential receptor phospho-coding mechanism by which changes in the GPCR phosphorylation pattern induced by specific ligand stimulation events are recognized by an array of phosphate-binding pockets located in the $\mathrm{N}$-terminal region of arrestin. These changes are subsequently translated to distinct conformations of arrestin that could be recognized by different downstream effector molecules.

To further examine whether the identified arrestin-involved phospho-coding mechanism could be generally applied to many GPCR members, we performed alanine substitution of specific phosphate-binding sites residues in $\beta$-arrestin- 1 and tested their functionalities upon interactions with different GPCRs, including $\beta_{2} \mathrm{AR}$, cholecystokinin type-A receptor (CCKAR), and somatostatin receptor type 2 (SSTR2). In accordance with the in vitro data, phosphate-binding site 4 was important for the $\beta$-arrestin-1/clathrin association, whereas site 5 was essential for the $\beta$-arrestin-1/SRC interaction, indicating the generality of the phospho-decision mechanism.

Taken together, as shown in Fig. 2, our results can be summarized as the flute model, in which phosphate-binding sites along the $\mathrm{N}$ terminus of $\beta$-arrestin- 1 resemble the holes in a flute. Different phosphorylation patterns of the receptor function as "fingers" and instruct the conformational changes within $\beta$-arrestin-1, resulting in different "melodies" that are correlated with distinct downstream signaling. At least 10 potential phosphate-binding sites in $\beta$-arrestin- 1 have been identified, which could potentially produce more than 1000 different sequence combinations $\left(2^{10}-1=1023\right)$ in a single arrestin molecule. In theory, these binding patterns are able to generate enough conformations of arrestin to facilitate its numerous downstream signaling events, thereby contributing to the divergent functionalities of the more than 800 known human GPCRs.

The barcode hypothesis arose from the observation that GPCRs are heterogeneously phosphorylated at multiple sites, which correlate with different cellular contexts and functions. It provides a theoretical basis for understanding how a single receptor could engage multiple distinct functions through arrestin. The dissection of the underlying mechanism of the barcode hypothesis led us to generate the flute model, a detailed illustration of and powerful complement to the barcode hypothesis. For the first time, this model reveals the mechanism by which the phospho-barcode on the ligandoccupied GPCR is precisely recognized by arrestin N-terminal phosphate-binding concave and turned into functional selective arrestin conformations that are correlated with distinct signaling pathways. According to the barcode hypothesis, a "biased" ligand for a GPCR modulates specific phosphorylation patterns and might activate only a selective set of signaling pathways in contrast to a "balanced" ligand, which nonselectively activates both $\mathrm{G}$ protein-mediated and phosphorylation/ arrestin-regulated physiologic responses (Luttrell, 2014; Wisler et al., 2014). Therefore, the barcode hypothesis has great potential in the development of therapeutic compounds that activate pathways that mediate beneficial effects over those initiating adverse responses. The newly proposed flute model provides mechanistic insight into this biased agonism in terms of arrestin conformational signaling and should further contribute to barcode-based novel drug design.

\section{Conclusion}

GPCR phosphorylation plays an important role in regulating GPCR function. The phospho-barcode concept developed over the past decade explains the multidimensional nature of the signaling network downstream of GPCRs and provides a potential mechanism by which GPCR functions are regulated through their interaction with arrestins. The flute model for phospho-barcoding further expands our knowledge, and preliminary data reveal that arrestins precisely recognize and transduce the phospho-message from the receptor by reading the message through its $\mathrm{N}$-terminal phospho-binding concave and generating specific conformations to recruit multiple effector molecules. The phospho-barcoding mechanism might function together with ligand-induced receptor core conformations, dictating arrestin-mediated signaling networks.

Because the phosphorylation patterns of a given receptor are ligand-specific, the phospho-barcoding machinery has great potential to be used in pharmaceutic development. These novel drugs are expected to selectively elicit signaling and therefore have enhanced therapeutic potentials.

However, despite accumulating in vitro evidence supporting the phospho-barcode, additional in vivo studies are required to further link the phosphorylation patterns of receptors to specific physiologic responses. Moreover, with more than 220 downstream effectors, the molecular mechanism underlying arrestin conformational signaling remains to be deciphered. More explicit structural information on receptor-arrestin-effector complexes, which might be disclosed by crystallography, electron microscopy, or NMR, is highly desirable.

\section{Authorship Contributions}

Participated in research design: Z. Yang, F. Yang, Yu, Sun.

Wrote or contributed to the writing of manuscript: Z. Yang, F. Yang, Zhang, Z. Liu, Lin, C. Liu, Xiao, Yu, Sun.

\section{References}

Ahn S, Wei H, Garrison TR, and Lefkowitz RJ (2004) Reciprocal regulation of angiotensin receptor-activated extracellular signal-regulated kinases by betaarrestins 1 and 2. J Biol Chem 279:7807-7811.

Attramadal H, Arriza JL, Aoki C, Dawson TM, Codina J, Kwatra MM, Snyder SH, Caron MG, and Lefkowitz RJ (1992) Beta-arrestin2, a novel member of the arrestin/beta-arrestin gene family. J Biol Chem 267:17882-17890.

Barki-Harrington L and Rockman HA (2008) Beta-arrestins: multifunctional cellular mediators. Physiology (Bethesda) 23:17-22.

Benovic JL, Pike LJ, Cerione RA, Staniszewski C, Yoshimasa T, Codina J, Caron MG, and Lefkowitz RJ (1985) Phosphorylation of the mammalian beta-adrenergic receptor by cyclic AMP-dependent protein kinase. Regulation of the rate of receptor phosphorylation and dephosphorylation by agonist occupancy and effects on coupling of the receptor to the stimulatory guanine nucleotide regulatory protein. $J$ Biol Chem 260:7094-7101. 
Benovic JL, Strasser RH, Caron MG, and Lefkowitz RJ (1986) Beta-adrenergic receptor kinase: identification of a novel protein kinase that phosphorylates the agonist-occupied form of the receptor. Proc Natl Acad Sci USA 83:2797-2801.

Bouvier M, Hausdorff WP, De Blasi A, O’Dowd BF, Kobilka BK, Caron MG, and Lefkowitz RJ (1988) Removal of phosphorylation sites from the beta 2 -adrenergic receptor delays onset of agonist-promoted desensitization. Nature 333:370-373

Bouzo-Lorenzo M, Santo-Zas I, Lodeiro M, Nogueiras R, Casanueva FF, Castro M, Pazos Y, Tobin AB, Butcher AJ, and Camiña JP (2016) Distinct phosphorylation sites on the ghrelin receptor, GHSR1a, establish a code that determines the functions of $\beta$-arrestins. Sci Rep 6:22495.

Bradley SJ, Wiegman CH, Iglesias MM, Kong KC, Butcher AJ, Plouffe B, Goupil E, Bourgognon JM, Macedo-Hatch T, LeGouill C, et al. (2016) Mapping physiological $\mathrm{G}$ protein-coupled receptor signaling pathways reveals a role for receptor phosphorylation in airway contraction. Proc Natl Acad Sci USA 113:4524-4529.

Budd DC, McDonald JE, and Tobin AB (2000) Phosphorylation and regulation of a Gq/11-coupled receptor by casein kinase $1 \alpha$. J Biol Chem 275:19667-19675.

Budd DC, Willars GB, McDonald JE, and Tobin AB (2001) Phosphorylation of the $\mathrm{Gq} / 11$-coupled m3-muscarinic receptor is involved in receptor activation of the ERK-1/2 mitogen-activated protein kinase pathway. J Biol Chem 276:4581-4587.

Burns RN, Singh M, Senatorov IS, and Moniri NH (2014) Mechanisms of homologous and heterologous phosphorylation of FFA receptor 4 (GPR120): GRK6 and PKC mediate phosphorylation of $\mathrm{Thr}^{347}, \mathrm{Ser}^{350}$, and $\mathrm{Ser}^{357}$ in the C-terminal tail. Biochem Pharmacol 87:650-659.

Busillo JM, Armando S, Sengupta R, Meucci O, Bouvier M, and Benovic JL (2010) Site-specific phosphorylation of CXCR4 is dynamically regulated by multiple kinases and results in differential modulation of CXCR4 signaling. J Biol Chem 285 7805-7817.

Butcher AJ, Hudson BD, Shimpukade B, Alvarez-Curto E, Prihandoko R, Ulven T, Milligan G, and Tobin AB (2014) Concomitant action of structural elements and receptor phosphorylation determines arrestin-3 interaction with the free fatty acid receptor FFA4. J Biol Chem 289:18451-18465.

Butcher AJ, Kong KC, Prihandoko R, and Tobin AB (2012) Physiological role of G-protein coupled receptor phosphorylation. Handb Exp Pharmacol (208):79-94.

Butcher AJ, Prihandoko R, Kong KC, McWilliams P, Edwards JM, Bottrill A, Mistry S, and Tobin AB (2011) Differential G-protein-coupled receptor phosphorylation provides evidence for a signaling bar code. J Biol Chem 286:11506-11518.

Celver JP, Lowe J, Kovoor A, Gurevich VV, and Chavkin C (2001) Threonine 180 is required for G-protein-coupled receptor kinase 3- and beta-arrestin 2-mediated desensitization of the mu-opioid receptor in Xenopus oocytes. J Biol Chem 276 $4894-4900$

Chen YJ, Oldfield S, Butcher AJ, Tobin AB, Saxena K, Gurevich VV, Benovic JL, Henderson G, and Kelly E (2013) Identification of phosphorylation sites in the COOH-terminal tail of the $\mu$-opioid receptor. $J$ Neurochem 124:189-199.

Cho EY, Cho DI, Park JH, Kurose H, Caron MG, and Kim KM (2007) Roles of protein kinase $\mathrm{C}$ and actin-binding protein 280 in the regulation of intracellular trafficking of dopamine D3 receptor. Mol Endocrinol 21:2242-2254.

Clark RB, Friedman J, Dixon RA, and Strader CD (1989) Identification of a specific site required for rapid heterologous desensitization of the beta-adrenergic receptor by cAMP-dependent protein kinase. Mol Pharmacol 36:343-348.

Couve A, Thomas P, Calver AR, Hirst WD, Pangalos MN, Walsh FS, Smart TG, and Moss SJ (2002) Cyclic AMP-dependent protein kinase phosphorylation facilitates $\mathrm{GABA}_{\mathrm{B}}$ receptor-effector coupling. Nat Neurosci 5:415-424.

Craft CM, Whitmore DH, and Wiechmann AF (1994) Cone arrestin identified by targeting expression of a functional family. J Biol Chem 269:4613-4619.

Daaka Y, Luttrell LM, and Lefkowitz RJ (1997) Switching of the coupling of the $\beta 2$ adrenergic receptor to different G proteins by protein kinase A. Nature 390:88-91.

Dalrymple MB, Jaeger WC, Eidne KA, and Pfleger KD (2011) Temporal profiling of orexin receptor-arrestin-ubiquitin complexes reveals differences between receptor subtypes. J Biol Chem 286:16726-16733.

DeWire SM, Ahn S, Lefkowitz RJ, and Shenoy SK (2007) Beta-arrestins and cell signaling. Annu Rev Physiol 69:483-510.

Dohlman HG (2015) Thematic minireview series: new directions in G protein-coupled receptor pharmacology. J Biol Chem 290:19469-19470.

Dong JH, Wang YJ, Cui M, Wang XJ, Zheng WS, Ma ML, Yang F, He DF, Hu QX, Zhang DL, et al. (2016) Adaptive activation of a stress response pathway improves learning and memory through Gs and $\beta$-arrestin-1-regulated lactate metabolism. Biol Psychiatry DOI: 10.1016/j.biopsych.2016.09.025 [published ahead of print].

Downes GB and Gautam N (1999) The G protein subunit gene families. Genomics 62 $544-552$.

Fredericks ZL, Pitcher JA, and Lefkowitz RJ (1996) Identification of the G proteincoupled receptor kinase phosphorylation sites in the human $\beta 2$-adrenergic receptor. J Biol Chem 271:13796-13803.

Galliera E, Jala VR, Trent JO, Bonecchi R, Signorelli P, Lefkowitz RJ, Mantovani A Locati M, and Haribabu B (2004) $\beta$-Arrestin-dependent constitutive internalization of the human chemokine decoy receptor D6. J Biol Chem 279:25590-25597.

Guetg N, Abdel Aziz S, Holbro N, Turecek R, Rose T, Seddik R, Gassmann M, Moes S, Jenoe P, Oertner TG, et al. (2010) NMDA receptor-dependent GABA Feceptor $_{\mathrm{B}}$ internalization via CaMKII phosphorylation of serine 867 in $\mathrm{GABA}_{\mathrm{B} 1}$. Proc Nat Acad Sci USA 107:13924-13929.

Gurevich EV, Tesmer JJ, Mushegian A, and Gurevich VV (2012) G protein-coupled receptor kinases: more than just kinases and not only for GPCRs. Pharmacol Ther 133:40-69.

Gurevich VV and Gurevich EV (2006) The structural basis of arrestin-mediated regulation of G-protein-coupled receptors. Pharmacol Ther 110:465-502.

Hanyaloglu AC, Vrecl M, Kroeger KM, Miles LE, Qian H, Thomas WG, and Eidne KA (2001) Casein kinase II sites in the intracellular C-terminal domain of the thyrotropin-releasing hormone receptor and chimeric gonadotropin-releasing hormone receptors contribute to beta-arrestin-dependent internalization. J Biol Chem 276:18066-18074.
Hausdorff WP, Caron MG, and Lefkowitz RJ (1990) Turning off the signal: desensitization of beta-adrenergic receptor function. FASEB J 4:2881-2889.

Jaeger WC, Seeber RM, Eidne KA, and Pfleger KD (2014) Molecular determinants of orexin receptor-arrestin-ubiquitin complex formation. $\mathrm{Br} J$ Pharmacol 171: 364-374

Jean-Charles PY, Rajiv V, and Shenoy SK (2016) Ubiquitin-related roles of $\beta$-arrestins in endocytic trafficking and signal transduction. J Cell Physiol 231: 2071-2080.

Jiang D and Sibley DR (1999) Regulation of $\mathrm{D}_{1}$ dopamine receptors with mutations of protein kinase phosphorylation sites: attenuation of the rate of agonist-induced desensitization. Mol Pharmacol 56:675-683.

Jones BW, Song GJ, Greuber EK, and Hinkle PM (2007) Phosphorylation of the endogenous thyrotropin-releasing hormone receptor in pituitary GH3 cells and pituitary tissue revealed by phosphosite-specific antibodies. J Biol Chem 282 12893-12906.

Kang Y, Zhou XE, Gao X, He Y, Liu W, Ishchenko A, Barty A, White TA, Yefanov O, Han GW, et al. (2015) Crystal structure of rhodopsin bound to arrestin by femtosecond X-ray laser. Nature 523:561-567.

Kara E, Crépieux P, Gauthier C, Martinat N, Piketty V, Guillou F, and Reiter E (2006) A phosphorylation cluster of five serine and threonine residues in the C-terminus of the follicle-stimulating hormone receptor is important for desensitization but not for beta-arrestin-mediated ERK activation. Mol Endocrinol 20:3014-3026

Kelly E, Bailey CP, and Henderson G (2008) Agonist-selective mechanisms of GPCR desensitization. Br J Pharmacol 153 (Suppl 1):S379-S388.

Khan SM, Sleno R, Gora S, Zylbergold P, Laverdure JP, Labbé JC, Miller GJ, and Hébert TE (2013) The expanding roles of $\mathrm{G} \beta \gamma$ subunits in G protein-coupled receptor signaling and drug action. Pharmacol Rev 65:545-577.

Kim J, Ahn S, Ren XR, Whalen EJ, Reiter E, Wei H, and Lefkowitz RJ (2005) Functional antagonism of different $\mathrm{G}$ protein-coupled receptor kinases for betaarrestin-mediated angiotensin II receptor signaling. Proc Natl Acad Sci USA 102: $1442-1447$

Kim OJ, Gardner BR, Williams DB, Marinec PS, Cabrera DM, Peters JD, Mak CC Kim KM, and Sibley DR (2004) The role of phosphorylation in D1 dopamine receptor desensitization: evidence for a novel mechanism of arrestin association. $J$ Biol Chem 279:7999-8010.

Kong KC, Butcher AJ, McWilliams P, Jones D, Wess J, Hamdan FF, Werry T, Rosethorne EM, Charlton SJ, Munson SE, et al. (2010) M3-muscarinic receptor promotes insulin release via receptor phosphorylation/arrestin-dependent activation of protein kinase D1. Proc Natl Acad Sci USA 107:21181-21186.

Kouhen OM, Wang G, Solberg J, Erickson LJ, Law PY, and Loh HH (2000) Hierarchical phosphorylation of delta-opioid receptor regulates agonist-induced receptor desensitization and internalization. $J$ Biol Chem 275:36659-36664.

Krupnick JG and Benovic JL (1998) The role of receptor kinases and arrestins in G protein-coupled receptor regulation. Annu Rev Pharmacol Toxicol 38:289-319.

Kühn H and Dreyer WJ (1972) Light dependent phosphorylation of rhodopsin by ATP. FEBS Lett 20:1-6.

Kumari P, Srivastava A, Banerjee R, Ghosh E, Gupta P, Ranjan R, Chen X, Gupta B, Gupta C, Jaiman D, et al. (2016) Functional competence of a partially engaged GPCR- $\beta$-arrestin complex. Nat Commun 7:13416.

Lamey M, Thompson M, Varghese G, Chi H, Sawzdargo M, George SR, and O'Dowd $\mathrm{BF}$ (2002) Distinct residues in the carboxyl tail mediate agonist-induced desensitization and internalization of the human dopamine D1 receptor. J Biol Chem 277:9415-9421.

Latorraca NR, Venkatakrishnan AJ, and Dror RO (2017) GPCR dynamics: structures in motion. Chem Rev 117:139-155.

Lee MH, Appleton KM, Strungs EG, Kwon JY, Morinelli TA, Peterson YK, Laporte SA, and Luttrell LM (2016) The conformational signature of $\beta$-arrestin2 predicts its trafficking and signalling functions. Nature 531:665-668.

Lefkowitz RJ (1998) G protein-coupled receptors. III. New roles for receptor kinases and beta-arrestins in receptor signaling and desensitization. J Biol Chem 273 : 18677-18680.

Lefkowitz RJ, Pierce KL, and Luttrell LM (2002) Dancing with different partners: protein kinase a phosphorylation of seven membrane-spanning receptors regulates their G protein-coupling specificity. Mol Pharmacol 62:971-974.

Liu XY, Mao LM, Zhang GC, Papasian CJ, Fibuch EE, Lan HX, Zhou HF, Xu M, and Wang JQ (2009) Activity-dependent modulation of limbic dopamine D3 receptors by CaMKII. Neuron 61:425-438.

Lohse MJ, Benovic JL, Codina J, Caron MG, and Lefkowitz RJ (1990) beta-Arrestin a protein that regulates beta-adrenergic receptor function. Science 248:1547-1550.

Lowe JD, Sanderson HS, Cooke AE, Ostovar M, Tsisanova E, Withey SL, Chavkin C, Husbands SM, Kelly E, Henderson G, et al. (2015) Role of G protein-coupled receptor kinases 2 and 3 in $\mu$-opioid receptor desensitization and internalization. $M o l$ Pharmacol 88:347-356.

Luttrell LM (2014) Minireview: more than just a hammer: ligand "bias" and pharmaceutical discovery. Mol Endocrinol 28:281-294.

Luttrell LM, Ferguson SS, Daaka Y, Miller WE, Maudsley S, Della Rocca GJ, Lin F, Kawakatsu H, Owada K, Luttrell DK, et al. (1999) Beta-arrestin-dependent formation of $\beta 2$ adrenergic receptor-Src protein kinase complexes. Science $\mathbf{2 8 3}$ : $655-661$.

Manglik A and Kobilka B (2014) The role of protein dynamics in GPCR function: insights from the $\beta 2 \mathrm{AR}$ and rhodopsin. Curr Opin Cell Biol 27:136-143.

McDonald PH and Lefkowitz RJ (2001) $\beta$-Arrestins: new roles in regulating heptahelical receptors' functions. Cell Signal 13:683-689.

Min L and Ascoli M (2000) Effect of activating and inactivating mutations on the phosphorylation and trafficking of the human lutropin/choriogonadotropin receptor. Mol Endocrinol 14:1797-1810.

Mukherjee S, Gurevich VV, Preninger A, Hamm HE, Bader MF, Fazleabas AT, Birnbaumer L, and Hunzicker-Dunn M (2002) Aspartic acid 564 in the third cytoplasmic loop of the luteinizing hormone/choriogonadotropin receptor is crucial for 
phosphorylation-independent interaction with arrestin2. J Biol Chem 277: 17916-17927.

Nakamura K, Hipkin RW, and Ascoli M (1998) The agonist-induced phosphorylation of the rat follitropin receptor maps to the first and third intracellular loops. Mol Endocrinol 12:580-591.

Namkung Y, Dipace C, Javitch JA, and Sibley DR (2009) G protein-coupled receptor kinase-mediated phosphorylation regulates post-endocytic trafficking of the D2 dopamine receptor. J Biol Chem 284:15038-15051.

Namkung Y and Sibley DR (2004) Protein kinase C mediates phosphorylation, desensitization, and trafficking of the D2 dopamine receptor. $J$ Biol Chem 279: 49533-49541.

Neumann-Staubitz P and Neumann H (2016) The use of unnatural amino acids to study and engineer protein function. Curr Opin Struct Biol 38:119-128.

Ning SL, Zheng WS, Su J, Liang N, Li H, Zhang DL, Liu CH, Dong JH, Zhang ZK, Cui M, et al. (2015) Different downstream signalling of CCK1 receptors regulates distinct functions of CCK in pancreatic beta cells. Br J Pharmacol 172:5050-5067.

Nobles KN, Guan Z, Xiao K, Oas TG, and Lefkowitz RJ (2007) The active conformation of beta-arrestin1: direct evidence for the phosphate sensor in the N-domain and conformational differences in the active states of beta-arrestins 1 and $-2 . J \mathrm{Biol}$ Chem 282:21370-21381.

Nobles KN, Xiao K, Ahn S, Shukla AK, Lam CM, Rajagopal S, Strachan RT, Huang TY, Bressler EA, Hara MR, et al. (2011) Distinct phosphorylation sites on the $\beta_{2^{-}}$ adrenergic receptor establish a barcode that encodes differential functions of $\beta$-arrestin. Sci Signal 4:ra51.

Ohguro H, Palczewski K, Ericsson LH, Walsh KA, and Johnson RS (1993) Sequential phosphorylation of rhodopsin at multiple sites. Biochemistry 32:5718-5724.

Palmer TM and Stiles GL (2000) Identification of threonine residues controlling the agonist-dependent phosphorylation and desensitization of the rat $\mathrm{A}_{3}$ adenosine receptor. Mol Pharmacol 57:539-545.

Pals-Rylaarsdam R and Hosey MM (1997) Two homologous phosphorylation domains differentially contribute to desensitization and internalization of the $\mathrm{m} 2$ muscarinic acetylcholine receptor. J Biol Chem 272:14152-14158.

Pals-Rylaarsdam R, Xu Y, Witt-Enderby P, Benovic JL, and Hosey MM (1995) Desensitization and internalization of the $\mathrm{m} 2$ muscarinic acetylcholine receptor are directed by independent mechanisms. J Biol Chem 270:29004-29011.

Peterhans C, Lally CC, Ostermaier MK, Sommer ME, and Standfuss J (2016) Functional map of arrestin binding to phosphorylated opsin, with and without agonist. Sci Rep 6:28686.

Pitcher J, Lohse MJ, Codina J, Caron MG, and Lefkowitz RJ (1992) Desensitization of the isolated beta 2 -adrenergic receptor by beta-adrenergic receptor kinase, cAMP-dependent protein kinase, and protein kinase $\mathrm{C}$ occurs via distinct molecular mechanisms. Biochemistry 31:3193-3197.

Pitcher JA, Freedman NJ, and Lefkowitz RJ (1998) G protein-coupled receptor kinases. Annu Rev Biochem 67:653-692.

Poulin B, Butcher A, McWilliams P, Bourgognon JM, Pawlak R, Kong KC, Bottrill A Mistry S, Wess J, Rosethorne EM, et al. (2010) The M3-muscarinic receptor regulates learning and memory in a receptor phosphorylation/arrestin-dependent manner. Proc Natl Acad Sci USA 107:9440-9445.

Prihandoko R, Alvarez-Curto E, Hudson BD, Butcher AJ, Ulven T, Miller AM, Tobin $\mathrm{AB}$, and Milligan G (2016) Distinct phosphorylation clusters determine the signaling outcome of free fatty acid receptor 4/G protein-coupled receptor 120 . Mol Pharmacol 89:505-520.

Qian H, Pipolo L, and Thomas WG (1999) Identification of protein kinase C phosphorylation sites in the angiotensin II (AT1A) receptor. Biochem $J$ 343:637-644

Rankin ML, Marinec PS, Cabrera DM, Wang Z, Jose PA, and Sibley DR (2006) The D1 dopamine receptor is constitutively phosphorylated by $\mathrm{G}$ protein-coupled receptor kinase 4. Mol Pharmacol 69:759-769.

Reiter E, Ahn S, Shukla AK, and Lefkowitz RJ (2012) Molecular mechanism of $\beta$-arrestin-biased agonism at seven-transmembrane receptors. Annu Rev Pharmacol Toxicol 52:179-197.

Ren XR, Reiter E, Ahn S, Kim J, Chen W, and Lefkowitz RJ (2005) Different G protein-coupled receptor kinases govern $\mathrm{G}$ protein and beta-arrestin-mediated signaling of V2 vasopressin receptor. Proc Natl Acad Sci USA 102:1448-1453.

Ritter SL and Hall RA (2009) Fine-tuning of GPCR activity by receptor-interacting proteins. Nat Rev Mol Cell Biol 10:819-830.

Seibold A, Williams B, Huang ZF, Friedman J, Moore RH, Knoll BJ, and Clark RB (2000) Localization of the sites mediating desensitization of the $\beta_{2}$-adrenergic receptor by the GRK pathway. Mol Pharmacol 58:1162-1173.

Shenoy SK and Lefkowitz RJ (2003) Multifaceted roles of beta-arrestins in the regulation of seven-membrane-spanning receptor trafficking and signalling. Biochem $J$ 375:503-515.

Shukla AK, Manglik A, Kruse AC, Xiao K, Reis RI, Tseng WC, Staus DP, Hilger D, Uysal S, Huang LY, et al. (2013) Structure of active $\beta$-arrestin-1 bound to a G-protein-coupled receptor phosphopeptide. Nature 497:137-141.

Shukla AK, Violin JD, Whalen EJ, Gesty-Palmer D, Shenoy SK, and Lefkowitz RJ (2008) Distinct conformational changes in beta-arrestin report biased agonism at seven-transmembrane receptors. Proc Natl Acad Sci USA 105:9988-9993.
Shukla AK, Westfield GH, Xiao K, Reis RI, Huang LY, Tripathi-Shukla P, Qian J, Li S, Blanc A, Oleskie AN, et al. (2014) Visualization of arrestin recruitment by a G-protein-coupled receptor. Nature 512:218-222.

Smith JS and Rajagopal S (2016) The $\beta$-arrestins: multifunctional regulators of G protein-coupled receptors. J Biol Chem 291:8969-8977.

Stadel JM, Nambi P, Shorr RG, Sawyer DF, Caron MG, and Lefkowitz RJ (1983) Catecholamine-induced desensitization of turkey erythrocyte adenylate cyclase is associated with phosphorylation of the beta-adrenergic receptor. Proc Natl Acad Sci USA 80:3173-3177.

Terunuma M, Vargas KJ, Wilkins ME, Ramírez OA, Jaureguiberry-Bravo M, Pangalos MN, Smart TG, Moss S.J, and Couve A (2010) Prolonged activation of NMDA receptors promotes dephosphorylation and alters postendocytic sorting of GABAB receptors. Proc Natl Acad Sci USA 107:13918-13923.

Thomas WG, Motel TJ, Kule CE, Karoor V, and Baker KM (1998) Phosphorylation of the angiotensin II (AT1A) receptor carboxyl terminus: a role in receptor endocytosis. Mol Endocrinol 12:1513-1524.

Tobin AB (2008) G-protein-coupled receptor phosphorylation: where, when and by whom. Br J Pharmacol 153 (Suppl 1):S167-S176.

Tobin AB, Butcher AJ, and Kong KC (2008) Location, location, location...site-specific GPCR phosphorylation offers a mechanism for cell-type-specific signalling. Trends Pharmacol Sci 29:413-420.

Torrecilla I, Spragg EJ, Poulin B, McWilliams PJ, Mistry SC, Blaukat A, and Tobin $\mathrm{AB}$ (2007) Phosphorylation and regulation of a $\mathrm{G}$ protein-coupled receptor by protein kinase CK2. J Cell Biol 177:127-137.

Villar VA, Jones JE, Armando I, Palmes-Saloma C, Yu P, Pascua AM, Keever L, Arnaldo FB, Wang Z, Luo Y, et al. (2009) G protein-coupled receptor kinase 4 (GRK4) regulates the phosphorylation and function of the dopamine D3 receptor. J Biol Chem 284:21425-21434.

Wang HL, Chang WT, Hsu CY, Huang PC, Chow YW, and Li AH (2002) Identification of two C-terminal amino acids, $\operatorname{Ser}(355)$ and $\operatorname{Thr}(357)$, required for short-term homologous desensitization of mu-opioid receptors. Biochem Pharmacol 64: 257-266.

Wang HM, Dong JH, Li Q, Hu Q, Ning SL, Zheng W, Cui M, Chen TS, Xie X, Sun JP, et al. (2014) A stress response pathway in mice upregulates somatostatin level and transcription in pancreatic delta cells through $\mathrm{G}_{\mathrm{s}}$ and $\beta$-arrestin 1. Diabetologia $\mathbf{5 7}$ $1899-1910$

Weller M, Virmaux N, and Mandel P (1975) Light-stimulated phosphorylation of rhodopsin in the retina: the presence of a protein kinase that is specific for photobleached rhodopsin. Proc Natl Acad Sci USA 72:381-385.

Wilden U and Kühn H (1982) Light-dependent phosphorylation of rhodopsin: number of phosphorylation sites. Biochemistry 21:3014-3022.

Wilden U, Wüst E, Weyand I, and Kühn H (1986) Rapid affinity purification of retina arrestin (48 $\mathrm{kDa}$ protein) via its light-dependent binding to phosphorylated rhodopsin. FEBS Lett 207:292-295.

Wisler JW, Xiao K, Thomsen AR, and Lefkowitz RJ (2014) Recent developments in biased agonism. Curr Opin Cell Biol 27:18-24.

Wu G, Bogatkevich GS, Mukhin YV, Benovic JL, Hildebrandt JD, and Lanier SM (2000) Identification of $\mathrm{G} \beta \gamma$ binding sites in the third intracellular loop of the M(3) muscarinic receptor and their role in receptor regulation. J Biol Chem 275: $9026-9034$

Wu S, Birnbaumer M, and Guan Z (2008) Phosphorylation analysis of G proteincoupled receptor by mass spectrometry: identification of a phosphorylation site in V2 vasopressin receptor. Anal Chem 80:6034-6037.

Xiao K and Liu H (2016) "Barcode" and differential effects of GPCR phosphorylation by different GRKs, in G Protein-Coupled Receptor Kinases (Gurevich VV, Gurevich EV, and Tesmer JJ eds) pp 75-120, Humana Press, New York.

Xiao K, Shenoy SK, Nobles K, and Lefkowitz RJ (2004) Activation-dependent conformational changes in beta-arrestin 2. J Biol Chem 279:55744-55753.

Xiao K, Sun J, Kim J, Rajagopal S, Zhai B, Villén J, Haas W, Kovacs JJ, Shukla AK Hara MR, et al. (2010) Global phosphorylation analysis of beta-arrestin-mediated signaling downstream of a seven transmembrane receptor (7TMR). Proc Natl Acad Sci USA 107:15299-15304.

Yang F, Yu X, Liu C, Qu CX, Gong Z, Liu HD, Li FH, Wang HM, He DF, Yi F, et al. (2015) Phospho-selective mechanisms of arrestin conformations and functions revealed by unnatural amino acid incorporation and ${ }^{19}$ F-NMR. Nat Commun 6: 8202

Zidar DA, Violin JD, Whalen EJ, and Lefkowitz RJ (2009) Selective engagement of G protein coupled receptor kinases (GRKs) encodes distinct functions of biased ligands. Proc Natl Acad Sci USA 106:9649-9654.

Address correspondence to: Dr. Jin-Peng Sun, Key Laboratory Experimental Teratology of the Ministry of Education and Department of Biochemistry and Molecular Biology, Shandong University School of Medicine, 44 Wenhua Xi Road, Jinan, Shandong, 250012, People's Republic of China. E-mail: sunjinpeng@sdu.edu.cn 